\title{
The Application of Headspace Solid-phase Microextraction as a Preparation Approach for Gas Chromatography with Mass Spectrometry
}

https://doi.org/10.15255/KUI.2020.020

KUI-34/2020

Review

Received April 3, 2020

Accepted May 12, 2020

\author{
I. Jerković, ${ }^{*}$ Z. Marijanović, ${ }^{b}$ A. Radonić, ${ }^{b}$ M. Zekić, and M. Kranjac ${ }^{a}$ \\ aniversity of Split, Faculty of Chemistry and Technology, Department of Organic Chemistry, \\ R. Boškovića 35, 21000 Split, Croatia \\ b University of Split, Faculty of Chemistry and Technology, Department of Food Technology and \\ Biotechnology, R. Boškovića 35, 21000 Split, Croatia
}

\begin{abstract}
Reviewed in brief are the selected results of the application of headspace solid-phase microextraction as a preparative approach for gas chromatography - mass spectrometry (HS-SPME/GC-MS) for natural organic compounds research at the University of Split, Faculty of Chemistry and Technology. A wide variety of headspace compounds from different natural sources has been identified: lower aliphatic compounds (e.g., $\mathrm{C}_{5}$ - and $\mathrm{C}_{6}$-compounds), aromatic compounds, monoterpenes (e.g., linalool derivatives (oxides, anhydro-oxides, epoxides), hotrienol), sesquiterpenes (e.g., eudesmol isomers, hydrocarbons), and $\mathrm{C}_{9}$ - and $\mathrm{C}_{13}$-norisoprenoids (e.g., 3,4-dihydro-3-oxoedulan, 4-oxoisophorone, trans- $\beta$-damascenone). These compounds are important phytochemicals as flavour/fragrance compounds, chemical markers of the botanical origin or others (e.g., allelochemicals, pheromones, or acaricide residue).
\end{abstract}

\section{Keywords}

Headspace solid-phase microextraction (HS-SPME), gas chromatography and mass spectrometry (GC-MS),

lower aliphatic compounds, aromatic compounds, monoterpenes, sesquiterpenes, $\mathrm{C}_{9}$ - and $\mathrm{C}_{13}$-norisoprenoids

\section{Introduction}

Headspace solid-phase microextraction (HS-SPME) is a sample preparation approach that has demonstrated its usefulness for a broad range of headspace volatile organic compounds (VOCs) in a variety of matrices. HS-SPME is based on the extraction of VOCs on the fibre coating that is proportional to their concentrations in the sample headspace. After extraction, the VOCs are desorbed from the coating material using thermal desorption (usually in gas chromatography injector) and transferred to the column for gas chromatographic separation most frequently combined with mass spectrometry (MS) detection. Recently published reviews have reported the most significant developments in the use of SPME for targeted and untargeted analysis. ${ }^{1-3}$

The main advantage of HS-SPME is the simplicity of its workflow, which uses coated devices with tuneable extraction phases, to extract targeted headspace VOCs from a given matrix. It has gained broad acceptance in general due to its suitability for direct application without pre-treatment of the sample; high selectivity for small compounds; suitability for non-destructive sampling; commercial availability of multiple coating types; reusability of the SPME fibres; and availability of autosampler (besides manual holder of the fibre) for non-supervised sample preparation and direct instrumental analysis.

This short review focuses on summarizing recent applications of HS-SPME/GC-MS for untargeted analysis of head-

*Corresponding author: prof. dr. sc. Igor Jerković

email: igor@ktf-split.hr space VOCs at the Faculty of Chemistry and Technology, University of Split in the last 10 years. Different fibres were used, but most frequently divinylbenzene/carboxene/polydimethylsiloxane (DVB/CAR/PDMS) and polydimethylsiloxane/divinylbenzene (PDMS/DVB). Chemical diversity of determined headspace VOCs from different natural sources is presented as follows: lower aliphatic compounds, aromatic compounds, terpenes (monoterpenes and sesquiterpenes), $\mathrm{C}_{9^{-}}$and $\mathrm{C}_{13}$-norisoprenoids. These compounds are important phytochemicals as flavour/fragrance compounds, chemical markers of the botanical origin or others (e.g., allelochemicals, pheromones, or acaricide residue).

\section{Lower aliphatic compounds}

Virgin olive oils (VOOs) obtained from Croatian autochthonous varieties Mašnjača and Krvavica were analysed by HS-SPME/GC-MS. ${ }^{4}$ The main headspace compounds were aliphatic $\mathrm{C}_{6}$-compounds derived from polyunsaturated fatty acids through lipoxygenase pathway. Krvavica oil was characterised by hexanal (8.8-9.4 \%), while (Z)-hex-3-enal (21.9-25.0 \%) and (E)-hex-2-enal (27.6-28.9\%) dominated in Mašnjača oil. The headspace volatiles of VOOs from Croatian autochthonous varieties Oblica, Lastovka, and Levantinka were also analysed by HS-SPME/GC-MS. ${ }^{5} \mathrm{C}_{6}$-Compounds were the main headspace volatiles responsible for green and fruity VOO sensory perception (they are produced through lipoxygenase pathway during the olive fruit crushing and malaxation, and incorporated into VOO). ${ }^{5}$ The most abundant was 
(E)-hex-2-enal (62.60-69.20\%). (Z)-Hex-3-enal was not found in Lastovka oil, while Levantinka oil contained no hexanal. ${ }^{5}$ Variable amounts of hexanal, hexan-1-ol, and hexyl acetate derive from degradation of linoleic acid, while (Z)-hex-3-enal, (E)-hex-2-enal, (E)-hex-2-enol, (Z)-hex-3-enol, and (Z)-hex-3-enyl acetate result from the enzymatic degradation of linolenic acid. ${ }^{6}$ Aliphatic alcohols (3-methylbutan-1-ol, 2-methylbutan-1-ol, pentan-1-ol, (Z)pent-2-en-1-ol, (Z)-hex-3-en-1-ol, and (E)-hex-2-en-1-ol) were the main headspace compounds found in Spanish Arbequina VOO (by HS-SPME/GC-MS). Sensory descriptors of $\mathrm{C}_{5}$ - and $\mathrm{C}_{6}$-alcohols are fruity, fresh, and grassy. ${ }^{7} \mathrm{An}$ increase in concentration of these compounds was found in all stressed olive trees (under deficit irrigation techniques to optimize water savings) as compared to the controls. ${ }^{7}$ The brand hydroSOStainable VOO was developed with the aim of improving functional and sensory characteristics of $\mathrm{VOO}$ under deficit irrigation techniques.

Isoamyl alcohol (3-methylbutan-1-ol; isopentanol) was the predominant (21.25-60.30 \%) headspace compound in late harvest (LHW) and ice harvest (IHW) Gewürztraminer wine samples from Ilok, Croatia. ${ }^{8}$ Isobutanol and isoamyl alcohol are essentially detrimental to wine quality. ${ }^{9}$ Isoamyl alcohol is the main aliphatic alcohol synthesized by yeast during fermentation from carbohydrates and amino acids via the anabolic pathway and Ehrlich pathway. $\alpha$-Keto acids are decarboxylated producing aldehydes, which are subsequently reduced to alcohols. $\alpha$-Keto acids are generated from carbohydrates via de novo biosynthesis of amino acids (the anabolic pathway) or are formed from amino acid breakdown (transamination) in Ehrlich pathway. ${ }^{10}$ However, the formation of alcohols does not always require an amino acid precursor. For example, $\alpha$-ketoisocaproate (a precursor to leucine and isoamyl alcohol) can be formed from a reaction between $\alpha$-ketobutyrate (pyruvate product) and acetyl CoA. ${ }^{11}$

Dipropyl disulphide, diisopropyl trisulphide, and (Z)-prop-1-enyl propyl trisulphide were predominant sulphides in Allium cornutum Clementi ex Visiani, 1842 headspace followed by a minor abundance of (E)-prop-1-enyl propyl trisulphide, methyl methylthiomethyl disulphide or allyl propyl disulphide. ${ }^{12}$ Another abundant compound was 1-propanethiol accompanied with a minor percentage of prop-2-en-1-thiol and methanethiol. In comparison with Allium cepa L., the abundance of several important headspace compounds was higher: dipropyl disulphide (1.5 times), 1-propanethiol (1.1 times), and methyl methylthiomethyl disulphide (5.6 times). On the other hand, several compounds in $A$. cornutum were present with lower percentages in $A$. cepa, such as (E)-prop-1-enyl propyl disulphide, (E)-prop-1-enyl propyl trisulphide, and trans-3,6-diethyl-1,2,4,5-tetrathiane. It is known that Allium species contain cysteine sulphoxides as precursors of volatile compounds. After disruption of onion tissue, the alliinase enzyme cleaves cysteine sulphoxides into the sulphinic acids, which are immediately converted to thiosulphinates that are chemically unstable and undergo dissociation and rearrangement to the volatile sulphur compounds responsible for specific onion odor ${ }^{13,14}$

\section{Aromatic compounds}

Phenylacetaldehyde, 2-phenylethanol, and benzaldehyde have been frequently found in different honey headspace by HS-SPME/GC-MS. ${ }^{15}$ However, those compounds cannot be considered specific chemical markers of the botanical origin in non-thermally treated honeys. Phenylacetaldehyde can be generated from phenylalanine either by enzyme catalysis or by Strecker degradation. ${ }^{15}$ Its content depends on phenylalanine content and storage conditions. Phenylacetaldehyde was found as dominant compound in Coffea spp. honey ${ }^{16}(36.6 \%)$, Amorpha fruticosa honey ${ }^{17}$ (38.3-58.4\%), Moltkia petraea (TRATT.) GRISEB. honey ${ }^{18}(12.8 \% ; 15.6 \%)$, and Trifolium pratense L. honey ${ }^{19}$ (10.1-31.2 \%). Shikimic acid derivative benzaldehyde was found dominant in the headspace of Moltkia petraea (TRATT.) GRISEB. honey ${ }^{18}$ (11.1\%; $\left.10.0 \%\right)$, Phacelia tanacetifolia Benth. honey ${ }^{20}(0.3-14.8 \%)$, and fir honeydew honey ${ }^{21}$ (13.8-43.7 \%). In Asphodelus microcarpus Salzm. et Viv. honey headspace, ${ }^{22} 31$ headspace volatile compounds were identified with high percentages of 2-phenylacetaldehyde (14.8-34.7\%), followed by lower percentages of methyl syringate (methyl 4-hydroxy-3,5-dimethoxybenzoate, 10.5-11.5\%). Methyl syringate is derived from 4-coumaric acid in shikimate pathway, and its content is an important chemical marker for A. microcarpus honey botanical origin. ${ }^{23}$ The presence of methyl salicylate $(1.8 \%)$ in the headspace of Salix spp. honeydew honey can be emphasized as a specific chemical biomarker since this compound has not been identified in other honey types. ${ }^{24}$

The major headspace compounds from four nectar varieties of Citrus unshiu Marc. ${ }^{25}$ were nitrogen-containing compounds $1 \mathrm{H}$-indole $(7.3-52.5 \%)$ and methyl anthranilate (3.0-19.8\%). Higher percentages of $1 \mathrm{H}$-indole were found in nectar of Okithu and Zorica varieties, and methyl anthranilate in nectar of Kawano Wase varieties. Those compounds derive from chorismate in the tryptophan biosynthetic pathway. PR-anthranilate transferase catalyses phosphoribosyl moiety transfer from phospho-ribosylpyrophosphate to anthranilate, and PR-anthranilate isomerase rearranges PR-anthranilate to 1-(O-carboxyphenylamino)-1-deoxyribulose-5-phosphate. Indole-3-glycerolphosphate synthase next forms an indole ring during the conversion of 1-(O-carboxyphenylamino)-1-deoxyribulose-5-phosphate to indole-3-glycerolphosphate. ${ }^{26}$

In several propolis samples, ${ }^{27}$ the most abundant compound detected by HS-SPME/GC-MS was thymol (31.4-76.0 \%). However, thymol is not a natural propolis constituent. It can be connected with anti-Varroa treatment, ${ }^{28}$ since thymol is a natural acaricide and the active ingredient of e.g., Apiguard, Apilife-VAR, and Thymovar. ${ }^{29}$ Therefore, HS-SPME/GC-MS can be used for acaricide residue detection in propolis.

\section{Terpenes}

A variety of monoterpenes and sesquiterpenes can be identified by HS-SPME/GC-MS from different natural sources. Among the typical propolis components, oxygenated sesquiterpenes dominated in the headspace (HS-SPME/ 
GC-MS) of Croatian propolis, ${ }^{27}$ such as $\alpha$-eudesmol (up to $19.9 \%$ ), $\beta$-eudesmol (up to $12.6 \%$,), and $\gamma$-eudesmol (up to $10.5 \%$ ). Eudesmol isomers are important as poplar type propolis chemical biomarkers. Other abundant compounds were the sesquiterpene hydrocarbons $\gamma$-cadinene (up to $21.4 \%$ ), $\alpha$-muurolene (up to $3.9 \%$ ), and cis-calamenene (up to $11.4 \%$ ). Numerous other sesquiterpenes were also present. ${ }^{27}$ Sesquiterpenes are derived biosynthetically from farnesyl pyrophosphate (FPP).

Among typical honey monoterpenes, a variety of linalool derivatives can be emphasized in the honey headspace. ${ }^{30}$ trans-Linalool oxide $(11.1 \% ; 14.6 \%)$ dominated in the headspace of Coriandrum sativum L. honey ${ }^{31}$ followed by other linalool derivatives such as cis/trans-anhydrolinalool oxide $(5.0 \% ; 5.9 \%)$, isomers of lilac aldehyde/alcohol (14.9\%; $13.8 \%$ ) or p-menth-1-en-9-al (15.6\%; $18.5 \%)$. The headspace of Phacelia tanacetifolia Benth. honey ${ }^{20}$ was characterized by linalool derivatives, including a particularly high level of trans-linalool oxide (19.1-52.8 \%) followed by a smaller amount of cis-linalool oxide (4.1-10.3\%), hotrienol (4.5-17.4\%), cis-/trans-epoxylinalool (0.0-2.6\% and $0.2-3.4 \%$, respectively), as well as lilac aldehyde isomers. Elevated, but much lower percentages of trans- and cis-linalool oxides were found in the headspace of one sample of Coffea spp. honey ${ }^{16}(20.5 \% ; 12.3 \%)$, Acer spp. honey $^{32}$ (20.5 \%; $4.1 \%$ ), and coriander honey ${ }^{31}$ (14.6\%; $3.3 \%)$. Lilac alcohols and aldehydes have been found in the headspace of different honey types, e.g., Citrus spp., ${ }^{25}$ Paliurus spina-christi Mill. ${ }^{33}$ or Coriandrum sativum L. ${ }^{30}$

Direct hydroxylation of linalool produces (E)-8-hydroxylinalool, which can give various products. Due to the acidic nature of honey, $(E)-8$-hydroxylinalool is probably transformed, via (E)-8-oxolinalool, by enzymatic oxidation to lilac alcohols that undergo oxidation to lilac aldehydes. ${ }^{34}$ Alternatively, epoxidation of linalool gives 6,7-epoxylinalool, which undergoes further reactions to form isomeric furanoid linalool oxides and anhydrolinalool oxides that can further yield lilac alcohols. ${ }^{30}$ Among 20 identified compounds, monoterpene alcohol hotrienol (3,7-dimethylocta-1,5,7-trien-3-ol) was predominant (75.9-81.7 \%) headspace compound of Satureja montana L. honey. ${ }^{35}$ It derives from dehydration of 2,6-dimethylocta-3,7-diene-2,6-di$\mathrm{ol}$, and it has been described as a sweet and flowery fragrance. ${ }^{36}$ Hotrienol was also found in Mentha spp. honey headspace (31.1-38.5\%). ${ }^{37}$

\section{Norisoprenoids}

$\mathrm{C}_{13}$ - and $\mathrm{C}_{9}$-norisoprenoids, a class of carotenoid-derived compounds with 3,5,5-trimethylcyclohex-2-enic structures, were the most abundant headspace compounds of Centaurea cyanus L. honey. ${ }^{38}$ The dominant 3,4-dihydro-3-oxoedulan $\quad(2,3,5,6,8,8 \mathrm{a}$-hexahydro-2,5,5,8a-tetramethyl-7H-1-benzopyran-7-one, or 2,5,5,8a-tetrame-
thyl-2,3,5,6,8,8a-hexahydro-7H-chromen-7-one) was found as $\mathrm{C}_{13}$-compound (18.60-44.97\%) and marked as specific chemical marker of this honey. ${ }^{38}$ Oxoedulan formation by intramolecular acid-catalysed conjugate addition may take place in acidic medium (e.g., hive conditions). Polyhydroxylated $\mathrm{C}_{13}$-norisoprenoids (e.g., 3 -hydroxy-retro- $\alpha$-ionol) are natural precursors of edulans. ${ }^{39}$ In addition, several lower molecular oxygenated $\mathrm{C}_{9}$-norisoprenoids were found: 4-oxoisophorone (3,5,5-trimethylcyclohex-2-ene-1,4-dione; 4.35-11.23\%), isophorone (3,5,5-trimethyl-cyclohex-2-en-1-one; 1.12-5.48 \%), and 2-hydroxyisophorone (2-hydroxy-3,5,5-trimethyl-2-hydroxycyclohex-2-en-1-one; $0.00-2.30 \%)$. $\mathrm{C}_{13}$-norisoprenoid trans- $\beta$-damascenone was abundant (8.3-13.0 \%) in Polish willow honey. ${ }^{40} \beta$-Damascenone and $\beta$-ionone, smelling like honey, exhibit the lowest odour threshold values of all $\mathrm{C}_{13}$-norisoprenoids. ${ }^{41}$ Carotenoids undergo chemical and enzymatic reactions generating norisoprenoids ${ }^{42}$ : (1) enzymatic (dioxygenases) as one-step direct carotenoid degradation or via glycosylation and breakdown of glycosides by the enzymes, and (2) non-enzymatic reactions involving one or several steps of carotenoid degradation, stimulated by light, oxygen, temperature, and acid hydrolysis. Carotenoids breakdown products are carbonyl compounds with 13,11, 10 or 9 carbon atoms retaining the terminal group of their carotenoid parent.

\section{Conclusions}

Reviewed is the application of HS-SPME as a preparation approach for GC-MS at the Faculty of Chemistry and Technology, University of Split in last 10 years. HS-SPME has demonstrated its usefulness for a broad range of headspace VOCs from a variety of matrices (e.g., olive oil, honey, propolis, or aromatic plants). A wide variety of headspace compounds was identified (applying DVB/CAR/PDMS and/or PDMS/DVB fibre): lower aliphatic compounds (e.g., $\mathrm{C}_{5}-$ and $\mathrm{C}_{6}$-compounds, isoamyl alcohol, dipropyl disulphide, diisopropyl trisulphide, (Z)-prop-1-enyl propyl trisulphide), aromatic compounds (e.g., phenylacetaldehyde, 2-phenylethanol, benzyl alcohol, $1 \mathrm{H}$-indole, methyl anthranilate, thymol), monoterpenes (e.g., linalool derivatives (oxides, anhydro-oxides, epoxides), hotrienol), sesquiterpenes (e.g., eudesmol isomers, hydrocarbons), and $\mathrm{C}_{9^{-}}$and $\mathrm{C}_{13}$-norisoprenoids (e.g., 3,4-dihydro-3-oxoedulan, 4-oxoisophorone, trans- $\beta$-damascenone). These compounds are important phytochemicals as flavour/fragrance compounds, chemical markers of the botanical origin or others (e.g., allelochemicals, pheromones, or acaricide residue). Several VOCs were present only in the sample headspace, but for full characterisation of the sample VOCs, the combination of HS-SPME with other methods of VOCs isolation is necessary (such as hydrodistillation, simultaneous distillation extraction or extraction) that would enable isolation of less-volatile compounds. 


\section{References \\ Literatura}

1. N. Reyes-Garcés, E. Gionfriddo, G. A. Gomez-Ríos, M. N. Alam, E. Boyacl, B. Bojko, V. Singh, J. Grandy, J. Pawliszyn, Advances in solid phase micro-extraction and perspective on future directions, Anal. Chem. 90 (2018) 302-360, doi: https://doi.org/10.1021/acs.analchem.7b04502.

2. E. A. Souza-Silva, R. Jiang, A. Rodríguez-Lafuente, E. Gionfriddo, J. Pawliszyn, A critical review of the state of the art of solid-phase microextraction of complex matrices I. Environmental analysis, Trends Anal. Chem. 71 (2015) 224-235, doi: https://doi.org/10.1016/j.trac.2015.04.016.

3. N. Reyes-Garcés, E. Gionfriddo, Recent developments and applications of solid phase microextraction as a sample preparation approach for mass-spectrometry-based metabolomics and lipidomics, Trends Anal. Chem. 113 (2019) 172-181, doi: https://doi.org/10.1016/j.trac.2019.01.009.

4. M. Šarolić, M., Gugić, C. I. G. Tuberoso, I. Jerković, M. Šuste, Z. Marijanović, P. M. Kuś, Volatile profile, phytochemicals and antioxidant activity of virgin olive oils from Croatian autochthonous varieties Mašnjača and Krvavica in comparison with Italian variety Leccino, Molecules 19 (2014) 881-895, doi: https://doi.org/10.3390/molecules19010881.

5. M. Šarolić, M., Gugić, E. Friganović, C. I. G. Tuberoso, I. Jerković, Phytochemicals and other characteristics of Croatian monovarietal extra virgin olive oils from Oblica, Lastovka and Levantinka varieties, Molecules 20 (2015) 4395-4409, doi: https://doi.org/10.3390/molecules20034395.

6. S. Vichi, J. M. Guadayol, J. Caixach, E. López-Tamames, S. Buxaderas, Comparative study of different extraction techniques for the analysis of virgin olive oil aroma, Food Chem. 105 (2007) 1171-1178, doi: https://doi.org/10.1016/j.foodchem.2007.02.018.

7. L. Sánchez-Rodríguez, M. Kranjac, Z. Marijanović, I. Jerković, M. Corell, A. Moriana, Á. A. Carbonell-Barrachina, E. Sendra, F. Hernández, Quality attributes and fatty acid, volatile and sensory profiles of "Arbequina" hydroSOStainable olive oil, Molecules 24 (2019) 2148-2164, doi: https://doi. org/10.3390/molecules24112148.

8. I. Jerković, Z. Marijanovć, G. Serreli, C. I. G. Tuberoso, Insight into the chemical diversity of late/ice harvest Gewürztraminer Wine. Chem. Biodivers. 15 (2018) e1800254, doi: https:// doi.org/10.1002/cbdv.201800254.

9. A. de-la-Fuente-Blanco, M.-P. Sáenz-Navajas, V. Ferreira, On the effects of higher alcohols on red wine aroma, Food Chem. 210 (2016) 107-114, doi: https://doi.org/10.1016/j. foodchem.2016.04.021.

10. J. H. Swiegers, E. J. Bartowsky, P. A. Henschke, I. S. Pretorius, Yeast and bacterial modulation of wine aroma and flavour, Australian, Aust. J. Grape Wine Res. 11 (2005) 139-173, doi: https://doi.org/10.1111/j.1755-0238.2005.tb00285.x.

11. P. Ribereau-Gayon, D. Dubourdieu, B. Doneche, A. Lonvaud, (Eds.) Handbook of Enology, Volume 1: The Microbiology of Wines and Vinification, John Wiley \& Sons Ltd, Chichester, UK, 2000

12. Ž. Fredotović, B, Soldo, M. Šprung, Z. Marijanović, I. Jerković, J. Puizina, Comparison of organosulfur and amino acid composition between triploid onion Allium cornutum Clementi ex Visiani, 1842, and common onion Allium cepa L., and evidences for antiproliferative activity of their extracts, Plants 9 (2020) 98, doi: https://doi.org/10.3390/plants9010098.

13. M. M. Poojary, P. Putnik, D. B. Kovačević, F. J. Barba, J. M. Lorenzo, D. A. Dias, A. Shpigelman, Stability and extraction of bioactive sulfur compounds from Allium genus processed by traditional and innovative technologies, J. Food Com- pos. Anal. 61 (2017) 28-39, doi: https://doi.org/10.1016/j. jfca.2017.04.007.

14. P. Rose, M. Whiteman, P. K. Moore, Y. Z. Zhu, Bioactive S-alk(en)yl cysteine sulfoxide metabolites in the genus Allium: The chemistry of potential therapeutic agents, Nat. Prod. Rep. 22 (2005) 351-368, doi: https://doi.org/10.1039/ B417639C.

15. I. Jerković, Volatile benzene derivatives as honey biomarkers, Synlett 24 (2013) 2331-2334, doi: https://doi. org/10.1055/s-0033-1338972.

16. I. Jerković, C. I. G. Tuberoso, P. M. Kuś, Z. Marijanović, M. Kranjac, Screening of Coffea spp. honey by different methodologies: theobromine and caffeine as chemical markers, RSC Adv., 4 (2014) 60557-60562, doi: https://doi.org/10.1039/ C4RA11105B.

17. I. Jerković, Z. Marijanović, J. Kezić, M. Gugić, Headspace, volatile and semi-volatile organic compounds diversity and radical scavenging activity of ultrasonic solvent extracts from Amorpha fruticosa honey samples, Molecules 14 (2009) 2717 doi: https://doi.org/10.3390/molecules14082717.

18. I. Jerković, Z. Marijanović, M. Zekić, C. I. G. Tuberoso, First report on rare unifloral honey of endemic Moltkia petraea (TRATT.) GRISEB. from Croatia: detailed chemical screening and antioxidant capacity, Chem. Biodivers. 14 (2017) e1600268, doi: https://doi.org/10.1002/cbdv.201600268.

19. I. Jerković, A. Radonić, M. Kranjac, M. Zekić, Z. Marijanović, S. Gudić, M. Kliškić, Red clover (Trifolium pratense L.) honey: volatiles chemical-profiling and unlocking antioxidant and anticorrosion capacity, Chem. Pap. 70 (2016) 726-736, doi: https://doi.org/10.1515/chempap-2016-0016.

20. P. M. Kuś, I. Jerković, Z. Marijanović, M. Kranjac, C. I. G. Tuberoso, Unlocking Phacelia tanacetifolia Benth. honey characterization through melissopalynological analysis, color determination and volatiles chemical profiling, Food Res. Int. 106 (2018) 243-253, doi: https://doi.org/10.1016/j.foodres.2017.12.065.

21. P. M. Kuś, I. Jerković, Z. Marijanović, C. I. G. Tuberoso, Screening of Polish fir honeydew honey using GC/MS, HPLC-DAD, and physical-chemical parameters: benzene derivatives and terpenes as chemical markers, Chem. Biodivers. 14 (2017) e1700179, doi: https://doi.org/10.1002/cbdv.201700179.

22. I. Jerković, C. I. G. Tuberoso, A. Kasum, Z. Marijanović, Volatile compounds of Asphodelus microcarpus Salzm. et Viv. honey obtained by HS-SPME and USE analyzed by GC/ MS, Chem. Biodivers. 8 (2011) 587-598, doi: https://doi. org/10.1002/cbdv.201000205.

23. C. I. G. Tuberoso, E. Bifulco, I. Jerković, P. Caboni, P. Cabras, I. Floris, Methyl syringate: a chemical marker of asphodel (Asphodelus microcarpus Salzm. et Viv.) monofloral honey, J. Agric. Food Chem. 57 (2009) 3895-3900, doi: https://doi. org/10.1021/jf803991j.

24. I. Jerković, Z. Marijanović, C. I. G. Tuberoso, D. Bubalo, N. Kezić, Molecular diversity of volatile compounds in rare willow (Salix spp.) honeydew honey: identification of chemical biomarkers, Mol. Divers. 14 (2010) 237-248, doi: https:// doi.org/10.1007/s11030-009-9164-6.

25. I. Jerković, S. Prđun, Z. Marijanović, M. Zekić, D. Bubalo, L. Svečnjak, C. I. G. Tuberoso, Traceability of Satsuma mandarin (Citrus unshiu Marc.) honey through nectar/honey-sac/honey pathways of the headspace, volatiles, and semi-volatiles: chemical markers, Molecules 21 (2016) 1302, doi: https:// doi.org/10.3390/molecules21101302.

26. E. R. Radwanski, R. L. Last, Tryptophan biosynthesis and metabolism: Biochemical and molecular genetics, Plant Cell 7 (1995) 921-934, doi: https://doi.org/10.1105/tpc.7.7.921.

27. I. Jerković, Z. Marijanović, P. M. Kuś, C. I. G. Tuberoso, 
Comprehensive study of Mediterranean (Croatian) propolis peculiarity: headspace, volatiles, anti-Varroa-treatment residue, phenolics, and antioxidant properties, Chem. Biodivers. 13 (2016) 210-218, doi: https://doi.org/10.1002/ cbdv.201500053.

28. M. G. Miguel, S. Nunes, C. Cruz, J. Duarte, M. D. Antunes, A. M. Cavaco, M. Mendes, A. S. Lima, L. G. Pedro, J. G. Barroso, A. C. Figueiredo, Propolis volatiles characterisation from acaricide-treated and -untreated beehives maintained at Algarve (Portugal), Nat. Prod. Res. 27 (2013) 743-749, doi: https://doi.org/10.1080/14786419.2012.696261.

29. S. Bogdanov, Contaminants of bee products, Apidologie 37 (2006) 1-18, doi: https://doi.org/10.1051/apido:2005043.

30. I. Jerković, P. M. Kuś, Terpenes in honey: occurrence, origin and their role as chemical biomarkers, RSC Adv. 4 (2014) 31710-31728, doi: https://doi.org/10.1039/C4RA04791E.

31. I. Jerković, M. Obradović, P. M. Kuś, M. Šarolić, Bioorganic diversity of rare Coriandrum sativum L. honey: unusual chromatographic profiles containing derivatives of linalool/ oxygenated methoxybenzene, Chem. Biodivers. 10 (2013) 1549-1558, doi: https://doi.org/10.1002/cbdv.201300074.

32. I. Jerković, Z. Marijanović, M. Malenica-Staver, D. Lušić, Volatiles from a rare Acer spp. honey sample from Croatia, Molecules 15 (2010) 4572-4582, doi: https://doi.org/10.3390/ molecules15074572.

33. I. Jerković, C. I. G. Tuberoso, Z. Marijanović, M. Jelić, A. Kasum, Headspace, volatile and semi-volatile patterns of $\mathrm{Pa}$ liurus spina-christi unifloral honey as markers of botanical origin, Food Chem. 112 (2009) 239-245, doi: https://doi. org/10.1016/j.foodchem.2008.05.080.

34. M. Kreck, S. Püschel, M. Wüst, A. Mosandl, Biogenetic studies in Syringa vulgaris L.: synthesis and bioconversion of deuterium-labeled precursors into lilac aldehydes and lilac alcohols, J. Agric. Food Chem. 51 (2003) 463-469, doi: https:// doi.org/10.1021/jf020845p.
35. I. Jerković, C. I. G. Tuberoso, Z. Marijanović, M. Kranjac, M. Malenica-Staver, Antioxidant capacity and chemical profiles of Satureja montana L. honey: hotrienol and syringyl derivatives as biomarkers, Chem. Biodivers. 12 (2015) 1047-1056, doi: https://doi.org/10.1002/cbdv.201400183.

36. E. Etzold, B. Lichtenberg-Kraag, Determination of the botanical origin of honey by Fourier-transformed infrared spectroscopy: an approach for routine analysis, Eur. Food Res. Technol. 227 (2008) 579-586, doi: https://doi.org/10.1007/ s00217-007-0759-9.

37. I. Jerković, G. Hegić, Z. Marijanović, D. Bubalo, Organic extractives from Mentha spp. honey and the bee-stomach: methyl syringate, vomifoliol, terpenediol I, hotrienol and other compounds, Molecules 15 (2010) 2911-2924, doi: https:// doi.org/10.3390/molecules15042911.

38. P. M. Kus, Z. Marijanovic, I. Jerkovic, Headspace compounds from Centaurea cyanus L. honey: the occurrence of 3,4-dihydro-3-oxoedulan, Chem. Nat. Comp. 49 (2013) 961-964, doi: https://doi.org/10.1007/s10600-013-0794-7.

39. M. Herderich, P. Winterhalter, 3-Hydroxy-retro- $\alpha$-ionol: a natural precursor of isomeric edulans in purple passion fruit (Passiflora edulis Sims), J. Agric. Food Chem. 39 (1991) 1270-1274, doi: https://doi.org/10.1021/jf00007a015.

40. I. Jerković, P. M. Kuś, C. I. G. Tuberoso, M. Šarolić, Phytochemical and physical-chemical analysis of Polish willow (Salix spp.) honey: Identification of the marker compounds, Food Chem. 145 (2014) 8-14, doi: https://doi.org/10.1016/j. foodchem.2013.08.004.

41. H.-D. Belitz, W. Grosch, P. Schieberle, (Eds.) Food Chemistry. Springer-Verlag, Berlin, $4^{\text {th }}$ Ed., 2009.

42. P. Winterhalter, R. Rouseff, in P. Winterhalter and R. Rouseff (Eds.), Carotenoid-Derived Aroma Compounds, ACS Symposium Series, American Chemical Society, Washington, DC, 2001, pp. 1-17. 


\section{SAŽETAK}

\section{Primjena mikroekstrakcije vršnih para na čvrstoj fazi kao preparativni pristup za plinsku kromatografiju sa spektrometrijom masa \\ Igor Jerković, ${ }^{*}$ Zvonimir Marijanović, ${ }^{b}$ Ani Radonić, ${ }^{\mathrm{b}}$ Marina Zekića i Marina Kranjaca}

Ukratko su prikazani odabrani rezultati primjene mikroekstrakcije vršnih para na čvrstoj fazi kao preparativnog pristupa plinskoj kromatografiji - spektrometriji masa (HS-SPME/GC-MS) za istraživanje prirodnih spojeva, koje je provedeno na Kemijsko-tehnološkom fakultetu Sveučilištu u Splitu. Velika raznolikost spojeva vršnih para istražena je iz različitih prirodnih izvora: niži alifatski spojevi (npr. $\mathrm{C}_{5}$ - i $\mathrm{C}_{6}$-spojevi), aromatski spojevi, monoterpeni (npr. derivati linaloola (oksidi, anhidro-oksidi, epoksidi), hotrienol), seskviterpeni (npr. eudezmol izomeri, ugljikovodici) te $\mathrm{C}_{9}$ - $\mathrm{i}$ $\mathrm{C}_{13}$-norizoprenoidi (npr. 3,4-dihidro-3-oksoedulan, 4-oksoisoforon, trans- $\beta$-damascenon). Ti su spojevi važne fitokemikalije kao spojevi aroma/mirisa, kemijski marker botaničkog podrijetla ili drugo (npr. aleokemikalije, feromoni ili ostatci akaricida).

\section{Ključne riječi}

Mikroekstrakcija vršnih para na čvrstoj fazi (HS-SPME), plinska kromatografija i spektrometrija masa (GC-MS), niži alifatski spojevi, aromatski spojevi, monoterpeni, seskviterpeni,

$\mathrm{C}_{9}-i \mathrm{C}_{13}$-norizoprenoidi

a Sveučilište u Splitu

Kemijsko-tehnološki fakultet

Zavod za organsku kemiju,

R. Boškovića 35, 21000 Split

b Sveučilište u Splitu

Kemijsko-tehnološki fakultet, Zavod za

prehrambenu tehnologiju i biotehnologiju

R. Boškovića 35, 21000 Split
Pregledni rad

Prispjelo 3. travnja 2020 Prihvaćeno 12. svibnja 2020. 